DOI: https://doi.org/10.32839/2304-5809/2021-11-99-76

UDC 657.62(073)

Blagoy Vitaliy, Tatarenko Anastasia

Kharkiv National University of Construction and Architecture

\title{
ENTERPRISE DEVELOPMENT PLANNING
}

Summary. The article examines the category of "strategy", "adaptation" and its relationship with enterprise development. The essence of strategic planning is determined. The relevance and importance of planning in the activities of enterprises is also determined. The study revealed a variety of and fundamental differences of opinion of scientists on the understanding of the concept "Adaptive development", because many scientists are not unanimous in defining it concept. The most common is the claim that adaptive development is the emergence of new or improvement of existing properties of the positive content, the value of which for the organization is related to the action of direct and indirect influences of the external environment on the activities of the enterprise. A modern enterprise in conditions of international competition should be inherent in leadership and high professionalism.

Keywords: development, planning, enterprises, strategy, adaptation, strategic planning.

Благой В.В., Татаренко А.А.

Харківський національний університет будівництва та архітектури

\section{ПЛАНУВАННЯ РОЗВИТКУ ПІДПРИЕМСТВА}

Анотація. У статті досліджено категорію «стратегія», «адаптація» їі взаємозв'язок з розвитком підприємств. Визначено суть стратегічного планування. Також визначено актуальність і важливість планування у діяльності підприемств. У ході дослідження було виявлено багатоваріантність та фундаментальну розбіжність поглядів науковців щодо розуміння поняття "адаптивний розвиток», оскільки багато вчених не одностайні в дефініції цього поняття. Найбільш поширеним є твердження, що адаптивний розвиток це виникнення нових або вдосконалення існуючих властивостей позитивногозмісту, значення яких для організації пов'язано з дією прямих та непрямих впливів зовнішнього середовища на діяльність підприємства. У рамках тематики роботи доцільно приділити особливу увагу техніко-технологічному напрямку, який включає в себе модернізацію, розробку та реалізацію програм техніко-технологічного оновлення виробництва,впровадження нових інноваційних матеріалів та технології їхньої обробки. Сучасні економічні умови, в яких підприемства здійснюють свою діяльність, за останні роки стрімко змінюються. Це зумовлюе формування вдосконалених цілей, постановку нових задач та миттеве реагування підприємства на будь-які зміни у навколишньому середовищі. Під впливом зовнішніх та внутрішніх фракторів формуються тенденщії подальшого розвитку підприемств загалом. Сучасному підприемству в умовах міжнародної конкуренції повинно бути притаманне лідерство та високий професіоналізм. Наполегливість у реалізації стратегії має на увазі свідоме зобов'язання вищого керівництва направляти ресурси й енергію організації на досягнення лідируючого положення на ринку. Подібно спортсменам, що змагаються на вищому рівні, під час відсутності належного настрою і готовності на будь-які жертви заради перемоги організації не мають ніяких шансів на успіх. Компанії, у яких вищому менеджменту не удалося настроїти співробітників на досягнення високих цілей, ніколи не досягти «вершин», оскільки працівники не мають стимулів до додаткових зусиль і розвитку свого потенціалу.

Ключові слова: розвиток, планування, підприемства, стратегія, адаптація, стратегічне планування.

Tntroduction. The economic conditions in Iwhich enterprises operate are constantly changing in recent years, which makes serious demands on the system of strategic business management, leads to the formation of new goals, mechanisms, tools not only in current activities but also in the long run. The main prerequisites for the success of the company and risk factors are now not only internal but also external factors, and success is associated with how well the company fits into the ever-changing, dynamic environment and adapts to new trends. Therefore, it is extremely important to identify the conceptual foundations of Ukrainian enterprises, key fundamental trends that will affect their functioning in the long run, ie those that will most affect the company's ability to be competitive in the vast majority of situations and manage strategic development. based on forecasts of the future state of the environment.

Enterprises are directly involved in the creation of fixed assets, have a significant impact on the economy as a whole, research on the ability of such enterprises to adapt to changes in their operating environment are especially relevant in today's economy of Ukraine.

The goal of the work. The aim of the work is to study and plan the theoretical foundations and analyze the adaptive development of enterprises in modern conditions.

The subject of research is a set of theoretical, methodological and practical tools for enterprise development.

The object of research is the enterprises of Ukraine.

Research methods. The theoretical and methodological basis of the study is a systematic approach to the study of adaptation processes, the method of synthesis and analysis, the method of theoretical generalization, tabular and graphical methods.

A. Subbotin, I. Kalaikov, L. Rastrigin, J. Tsypkin, V. Skurikhin, Y. Sukhoverkha, E. Pettigrew, R. Vipp, P. Yarzabovsky, E. Lofqvist, I. Stenzaker, T . Landina, M. Budnik, B. Efendiev, T. Pilat, T. Grinko and other researchers. 
Results. When conducting research on the development of the enterprise, first of all, it is advisable to define its essence as an economic indicator. Issues related to the definition and study of adaptive development of the enterprise are given considerable attention in the works of leading scientists [1-10].

It should be noted that the process of development of any systems, including economic ones, presupposes that economic entities have the property of adaptation, which is manifested in the generally accepted form as an adaptation to the external environment and to the existing conditions. The emergence and survival of organizations is possible only if the conditions of their internal and external environment [10]. Development, the transition of enterprises to a higher degree in the economic system due to the need for adaptation. Thus, development and adaptation are inseparable processes.

The study revealed the diversity and fundamental differences of opinion of scientists on the understanding of the concept of "adaptive development", as many scientists are not unanimous in the definition of this concept.

The most common statement is that adaptive development is the emergence of new or improvement of existing properties of positive content, the importance of which for the organization is associated with the direct and indirect effects of the external environment on the enterprise [5].

In my opinion, adaptive development should be understood as the transition of enterprises to a higher level, adapting to the external environment and the existing conditions.

Taking into account the peculiarities of the functioning of industries, which is manifested in the long operating cycle, significant capital intensity, complexity of production links, the structure of the operating cycle, as well as pricing and based on the results and certain features of the analyzed concepts. and a multifaceted economic category, the essence of which is to constantly improve the economic performance of the enterprise and increase its competitiveness, due to a set of measures with an emphasis on innovation in production and management [1].

For a comprehensive study of the theoretical aspects of adaptive development, it is advisable to explore areas of adaptive development of enterprises [7].

The main ones are:

1) organizational and managerial;

2) economic;

3) technical and technological;

5) unconventional.

Within the framework of the subject of work it is expedient to pay special attention to the technical and technological direction, which includes modernization, development and implementation of programs of technical and technological renewal of production, introduction of new innovative materials and technologies of their processing.

Growth in the industries indicates economic and social development in the country. It should be noted that all sectors are related to other sectors of the economy, providing all sectors of the economy with fixed assets and providing certain services for their maintenance in the future. The development of other sectors of the economic system is important for achieving a balanced balance among the main areas of the economy.

An important role in planning requires high-quality provision of all necessary resources: human, financial, energy, information, technology [11].

The next task of the thesis is to analyze the main trends of adaptive development of enterprises in the construction industry.

Modern economic conditions in which enterprises operate in recent years are changing rapidly. This leads to the formation of improved goals, setting new goals and the immediate response of the company to any changes in the environment. Under the influence of external and internal factors, trends in the further development of enterprises in general are formed. Therefore, it is advisable to highlight the factors of influence of the external and internal environment that directly affect the sectoral characteristics of enterprises.

External factors of influence include:

- economic, political, social and epidemiological situation in the country;

- inflation rate;

- demand for products, works and services;

- income level of the population;

- level of resource provision.

Internal factors of influence include:

- level of qualification of employees;

- the level of cost of products, works, services;

- level of information provision;

- the amount of own financial resources and the availability of sources for raising capital [9].

Each of the above factors directly affects both the formation of trends in enterprises and the process of their adaptation to modern business conditions.

Considering external factors, it should be noted that all industries are very sensitive to economic, political, social and, as it turned out, epidemiological changes in the country.

First of all, consider the concept of "deregulation", which is also called "deregulation", which means the abolition or reduction of state regulation in a particular area of public relations. Most often, it means softening or reducing state control over doing business in various spheres of public life (politics, economics, construction, etc.) [17].

Deregulation in construction became one of the key reforms, which helped to increase Ukraine's position in the ranking of ease of doing business Doing Business-2018, where it ranked 76th among 190 countries. According to the indicator "Obtaining building permits", Ukraine entered the TOP40 countries, increasing its position from 140th place to 35 th [18].

The strategic goals of this reform are:

- reducing the number of inspections, regulatory procedures and reasons for contact between business and government;

- creation of an effective regulatory environment;

- creating a favorable environment for doing business.

The presented reform envisages reduction of the number of permitting documents in the field of economic activity subject to licensing, abolition 
of regulatory acts that complicate business activities, reduction of the number of state supervision (control) bodies, as well as provision of electronic services to citizens and businesses. is especially relevant in connection with the deterioration of the epidemiological situation in the country and the introduction of quarantine restrictions [19].

Recently, issues related to the introduction of energy-efficient technologies and equipment in all sectors of the economy have become increasingly important. These include:

- introduction of new and improvement of existing energy-saving technologies and equipment;

- reduction of energy costs;

- improving product quality, reducing raw material costs.

There are two types of key goals and results of the enterprise: financial and strategic.

Financial goals reproduce the urgent needs of the company to ensure its normal operation and effective results, ie they determine the overall conditions of survival of the company. Financial goals are usually set for a shorter period of time than strategic goals and should reflect changes in the industry, the market, or the company itself.

Strategic goals - relate more to the direction of strengthening the company's position in the industry, maintaining and enhancing its long-term competitive position in the market. These goals are usually set for longer periods compared to financial goals and are aimed at achieving an effect in the distant future.

In an unstable environment, strategic planning is gaining importance. At the present stage of the market economy, domestic enterprises of Ukraine must independently determine the goals of longterm operation and choose ways to achieve key results of their activities. In the case when managers (owners) of enterprises are aimed at long-term functioning in the market, it is natural that the system of planning the activities of the enterprise becomes strategic.

At the enterprises of Ukraine strategic planning is almost not carried out and therefore specialists and managers domestic enterprises, including trade ones, do not have experience, knowledge and do not know the advantages of strategic planning. One of the reasons is that the methods of strategic planning used in foreign practice are not adapted to the domestic market, and as a result, the results of their use are not always satisfactory.

Another reason is the inconsistency of planning methods and tools used, which, in turn, is due to a lack of understanding of the importance of existing relationships between tools and methods of strategic planning. Many practitioners, focusing on some popular methods and tools, overlook strategic planning as a whole [21].

Modern enterprise in the conditions of international competition should have leadership and high professionalism. Persistence in the implementation of the strategy implies a conscious commitment of senior management to direct the resources and energy of the organization to achieve market leadership. Like athletes competing at the highest level, in the absence of a proper mood and readiness for any sacrifice for the sake of victory, the organization has no chance of success. Com- panies in which senior management has failed to set employees up to achieve high goals will never reach the top, as employees have no incentive to put in the extra effort and develop their potential.

The pursuit of leadership does not necessarily mean global dominance in all major markets. For small businesses, it makes sense, at least initially, to become a leader in selected niches, in specific channels or distribution in a particular market segment. On the other hand, the concept of persistence in implementing the strategy is a recognition of the fact that companies with a small market share are extremely vulnerable.

During an economic downturn, consumers, resellers and retailers are more likely to deal with their big competitors. The sales volume of a small company will eventually be reduced and will not allow to maintain the required level of service and investment in new products and markets.

Persistence in the implementation of the strategy is a common vision, an idea that lives not one year, but ten or more years and goes into the distant future. The basic business skills and infrastructure needed to become better cannot be acquired or created in one day, and once they appear, they must be constantly adapted to change and improved. The difficulty is that some people are able to remain enthusiastic and faithful to the goals that will be achieved in ten to twenty years. Therefore, the company's top managers develop a program that includes a sequence of stages designed for the short term and at the same time conducive to achieving the ultimate goal. This program includes tasks related to the introduction of new models, entering new markets, reducing costs and improving quality. Such programs give employees the opportunity to feel their relevance and take care of the urgency of the work performed, to develop the necessary qualities, to set milestones in the implementation of plans, to analyze what has been achieved.

Conclusions. Strategic planning is planning from the future to the present based on global ideas and goals of the enterprise. Strategy is not a function of time, but a function of the set goal of development, a specific, spatially oriented direction of development. It is based, on the one hand, on the goals and objectives set during the development of the strategy, and on the other - on the forecasts in various areas of development. It should always be remembered that the application of strategic planning creates the most important advantages in the functioning of the enterprise: it prepares the enterprise for changes in the external environment; connects its resources with changes in the external environment; clarifies the problems that arise; coordinates the work of its various structural units; improves control at the enterprise. Also, strategic planning aimed at solving cardinal problems must be supported by current planning, which ensures the achievement of strategic goals. Of course, this should ensure the continuity of plans, their relationship, although the structure of planning decisions, planning methods and deadlines will differ. In my opinion, strategic planning can be the reason why many domestic companies will be able to stabilize their activities and get the necessary impetus for further development. 


\section{References:}

1. Marinenko N.Yu. (2016) Dialectical analysis of the concepts of "adaptation" and "adaptive development". Global and national economic problems, no. 13. Available at: http://global-national.in.ua/archive/13-2016/64.pdf (accessed 23 May 2021).

2. Nalyvaiko T.L. (2019) Identification of the conceptual and categorical apparatus of adaptive control. Agrosvit, no. 9, pp. 95-102.

3. Krisko J.L. (2019) Adaptation of the enterprise to the external environment through the mechanism of restructuring. Galician Economic Bulletin, no. 2, pp. 38-42.

4. Yakimenko-Tereshchenko N.V., Kozhurina L.S. (2017) Adaptive enterprise management in modern conditions: purpose and implementation mechanism. Young Scientist, no. 6(46), pp. 535-538.

5. Kryvobok K.V. (2018) Substantiation of the modern approach to adaptation of the enterprise to the unstable external environment. Economy and society, no. 14, pp. 412-420.

6. Grosul V.A., Askerov T.T. (2019) The essence and key aspects of adaptation of retail enterprises. Intelligence XXI, no. 2 , pp. 22-26.

7. Stets I.I. (2017) Adaptive enterprise management. Global and national economic problems, no. 18. Available at: http://global-national.in.ua/archive/18-2017/58.pdf

8. Kalinichenko Z. (2020) Problems of adaptive management of business systems in the influence of destabilizing factors in Ukraine. Scientific Bulletin of Dnipropetrovsk State University of Internal Affairs, no. 3, pp. $222-230$.

9. Gerasimova O.L., Podolyan M.V., Chachkova A.V. (2017) Adaptation of the enterprise to changes in the external environment as a means of ensuring its economic security. Economics and business management, no. 6 , pp. 141-146.

10. Siketina N.G. (2020) Theoretical basis for the formation of the system of adaptation of an industrial enterprise to the conditions of a changing competitive environment. Eastern Europe: economy, business and management, no. 2 , pp. 287-291.

11. Seryogina N.V., Sosnitskaya N.O., Vishnya Y.C. (2020) Analysis of the construction industry of Ukraine. Problems of system approach in economy, no. 3, pp. (77)-1. Available at: http://www.psae-jrnl.nau.in.ua/journal/ 3_77_1_2020_ukr/13.pdf

12. State Statistics Service of Ukraine: website. Available at: http://www.ukrstat.gov.ua/ (accessed 23 May 2021).

13. Express issue of the State Statistics Service of Ukraine dated April 29, 2021: website. Available at: https://ukstat.gov.ua (accessed 23 May 2021).

14. Official site of Avtomagistral-Pivden: website. Available at: http://automagistral.com.ua/project/vzlyotnoposadochnaya-polosa-odessa/

15. Ukrinform Multimedia platform of foreign broadcasting of Ukraine: website. Available at: https://www.ukrinform.ua/ rubric-economy/3241615-novu-zlitnoposadkovu-smugu-odeskogo-aeroportu-vidkriut-vlitku-2021-roku.html (accessed 05 June 2021).

16. Vox Ukraine Analytical platform: website. Available at: https://voxukraine.org/velike-budivnitstvo-shhovidbuvayetsya-z-remontom-dorig/ (accessed 05 June 2021).

17. Information reference prepared by the European Information and Research Center at the request of the People's Deputy of Ukraine. Available at: http://radaprogram.org/sites/default/files/infocenter/piblications/69.pdf

18. Doing business-2018. Ukraine is ranked by the World Bank as an ease of doing business. Economic Discussion Club. Available at: http://edclub.com.ua/analityka/doing-business-2018-ukrayina-v-reytyngu-svitovogo-bankulegkosti-vedennya-biznesu (accessed 05 June 2021).

19. Analytical report for 2019 of the State Regulatory Service of Ukraine. Available at: https://www.kmu.gov.ua/ storage/app/sites/1/17-civik2018/zvit_2019/zvit-2019-reguliator.pdf (accessed 07 June 2021).

20. State program "Large construction". Available at: https://bigbud.kmu.gov.ua/

21. Innovations in construction: why Ukrainian developers are not interested in new technologies. Special project Mind Innovation Index. Available at: https://mind.ua/publications/20202837-innovaciyi-v-budivnictvi-chomuukrayinski-developeri-ne-cikavlyatsya-novimi-tehnologiyami (accessed 07 June 2021). 